\title{
SINTAKSIČKI POKAZATELJI POLNOLEKTA U KASNIJOJ FAZI JEZIČKOG RAZVOJA
}

Kada govore i pišu, muškarci i žene na različite načine koriste jezička sredstva. Na tome se zasniva teorija o polnolektima koja pokušava da objasni u čemu se te razlike ogledaju, što je poslednjih godina podstaklo mnoga istraživanja na ovu temu. Cilj rada je da se ispitaju sintaksička svojstva tekstova učenika mlađeg osnovnoškolskog uzrasta i razlike u njihovoj produkciji između dečaka i devojčica. U istraživanju je učestvovao 181 učenik (96 dečaka i 85 devojčica) od I do IV razreda. Svi su pisali po tri sastava, tako da su u korpus za analizu ušla ukupno 543 teksta. Analiza je obuhvatila kvantitativne (dužina teksta izražena brojem reči, brojem komunikativnih rečenica i brojem klauza) i kvalitativne (različiti tipovi rečenica) sintaksičke pokazatelje. Analizirane su razlike među polovima u odnosu na ispitivane varijable. Na osnovu dobijenih rezultata može se zaključiti da se razlike između tekstova koje su pisali dečaci i devojčice na mlađem osnovnoškolskom uzrastu odnose na kvantitativne pokazatelje, dok u stepenu sintaksičke složenosti, tj. zrelosti produkovanih tekstova nema značajnih razlika.

Ključne reči: pisanje, sintaksa, razlike, pol, polnolekt, kasniji jezički razvoj

\footnotetext{
* majapivanovic@gmail.com

** Rad je proistekao iz projekata Jezici i kulture u vremenu i prostoru OI $178002 \mathrm{i}$ Evaluacija tretmana stečenih poremećaja govora i jezika, OI 179068, čiju realizaciju finansira Ministarstvo prosvete, nauke i tehnološkog razvoja Republike Srbije.
} 
Maja P. Ivanović / Jelena P. Đorđević

\section{UVOD}

\section{Da li se razlikuje govor muškaraca i žena?}

Sredinom sedamdesetih godina dvadesetog veka u lingvistici se pojavljuju radovi koji ispituju potencijalne razlike u govoru muškaraca i žena. Poznata studija Robin Lejkof Language and woman's place (Lakoff, 1975) označava začetak teorije o polnolektima polazeći od popularnih shvatanja da postoji čitav niz karakteristika različitih oblika govora koje se povezuju s jednim polom. Kao opšti zaključak se navodi da je ,,jezik muškaraca“ jedan od ključnih mehanizama za uspostavljanje i održavanje dominacije nad ženama. Istovremeno je ovom teorijom dominacije otpočela i prva faza rodnih studija u lingvistici (Filipović, 2011).

$\mathrm{U}$ radovima koji su usledili polne razlike su ispitivane na brojnim primerima govorne delatnosti, od izgovora, intonacije, do sintaksičke organizacije diskursa i teksta. Analize su pokazale postojanje brojnih različitosti na gotovo svim jezičkim nivoima. Zaključci do kojih se došlo mogu se svesti na dva ključna: ili je reč, kako su pojedini autori smatrali, o jeziku žena (women's language), ili o nekoj vrsti ženskog dijalektau okviru istog jezika (Savić, 1995), kako su isticali drugi. U oba slučaja naglašavaju se razlike u jeziku koje se vezuju za pol govornika; međutim, dok je u prvom reč o sasvim drugačijem jeziku, dotle se u drugom priznaje samo delimično odstupanje od „norme“ muškog govorenja (Savić, 1995).Ana Bodin ističe da se postojeće razlike mogu posmatrati kaoosobine u jeziku koje su svojstvene samo jednom polu (sex-exclusive), ili kao onekoje su u svojoj suštini univerzalne, tj. koje se mogu naći i kod muškaraca i kod žena, alikod kojih postoji tendencija da ih više upotrebljavaju pripadnici jednog pola, te se na taj način mogu okarakterisatikao pretežno „muške” odnosno ,ženske"(sex-preferential) (Bodine, 1975).

Sociolingvistička istraživanja u oblasti polnolekta nastoje da identifikuju razlike i skrenu pažnju na različite vrste i nivoe komunikacije među polovima (Tannen, 1990). Teorija o polnolektima se u svojim počecima oslanjala na binarnu konceptualizaciju roda koja razlike u jezičkoj upotrebi između muškarca i žene sagledava kao isključivo biološke, tj. genetske. Danas je ovakvo gledište doživelo značajnije promene. Smatra se da je ključno pitanje u teorijsko-metodološkom smislu da li u studijama koje se bave pitanjima jezika i polnih/rodnih klasifikacija treba krenuti od bioloških kategorija muško-žensko, ili od socijalnih konstrukata feminiteta i 
maskuliniteta i njihovih uticaja na jezik (Cameron, 1997, prema Filipović, 2011). Stepen maskuliniteta ili feminiteta svakako može da varira, te se ove rodne razlike moraju uzeti u obzir prilikom analize polnolekta, bez obzira nato da li je neko muškog ili ženskog pola(Talbot, 2010: 12,13).

Osamdesete godine prošlog veka donose novu fazu u proučavanju rodnih studija; teoriju dominacije zamenjuje teorija različitosti ili model dve kulture koja teži da žene postavi u egalitarniji položaj u odnosu na muškarce, ne gubeći, pritom, iz vida različitosti njihove govorne delatnosti (Filipović, 2011). Prema ovom modelu muškarci i žene potiču iz različitih kultura jer odrastaju u različitom okruženju. Čak i kada dečak i devojčica rastu u istoj porodici, oni ipak ne odrastaju u istom svetu jer im se odrasli na različite načine obraćaju, pa shodno tome, i jedno i drugo razvijaju i posebne obrasce komunikacije. Komunikativni modeli se formiraju na osnovu kulturološkog iskustva, što je glavni razlog za pojavu rodnih razlika u jeziku (Tannen, 1994).

Poslednjih godina $\mathrm{u}$ istraživanjima koja se bave polnolektima, najviše pristalica ima teorija performativnosti. Njen tvorac, Batler (Butler, 1990), smata da u potpunosti treba isključiti naše polne (biološke) karakteristike, jer se niko ne rađa kao muško ili žensko, nego svako tokom života sam izgrađuje svoje rodne odlike (Filipović, 2011).

\section{Da li se razlikuje govor dečaka i devojčica?}

Socijalna biologija i evoluciona psihologija odbacuju pretpostavku da su obeležja roda $u$ jeziku rezultat uticaja društva pokušavajući da $u$ njima uoče genetsku osnovu. Tako se tvrdi da postoje razlike u lateralizovanosti moždanih hemisfera - slabija lateralizovanost se povezuje sa ženskim mozgom, na osnovu čega se izvodi zaključak da su žene izložene manjem riziku od nastanka oštećenja govora pošto kod njih centar za jezičke aktivnosti nije smešten samo u levoj hemisferi, što se ipak ne može uzeti kao dokaz za postojanje razlika u govornoj delatnosti između muškaraca i žena (Rathmayr, 2014).

S druge strane, sve su brojniji istraživači koji smatraju da je uticaj sredine presudan za budući način govorenja i pisanja deteta. Lingvistkinja Mari Talbot smatra da ne možemo tvrditi da devojčice i dečaci poseduju urođene osobine koje su odgovorne za razvoj polnolekta (Talbot, 2010). Odrasli uglavnom ne razgovaraju na isti način sa devojčicama i dečacima, što ide u prilog pretpostavci da proces kreiranja rodnih razlika počinje od- 
mah po rođenju. Prema ovoj tvrdnji jezik je ponašanje koje je zasnovano na rodnim razlikama, dok su polnolekti društveni konstrukti kojima jezik omogućava razlikovanje karakteristika koje prepoznajemo kao muške ili ženske (McKee, 2009). U istraživanju se pokazalo da vaspitači ne podstiču na isti način devojčice i dečake na upotrebu ekspresiva (hvala, izvoli, izvini i sl.). Devojčice se u prikladnoj situaciji opominju rečenicom „Kako se kaže?" dok se u istoj situaciji dečacima pruža model poželjnog ponašanja (jednostavno im kažu „hvala“) (Savić, 1995).Gudvin je analizirao upotrebu direktiva kod afroameričke dece i povezao uočene razlike u govoru između dečaka i devojčica sa polnom pripadnošću - dečacima naredbe služe za podsticanje na takmičenje u igri, dok su one kod devojčica u službi poziva na saradnju (Goodwin, 1980; prema Savić, 1995). Druga ispitivanja polnih razlika u jeziku potvrđuju da su devojčice najčešće nešto uspešnije u govornoj produkciji, u razumevanju pročitanog i u poznavanju leksičke semantike (Hyde \& Linn, 1988; prema Berko-Gleason \& Ely, 1997).

\section{CILJ}

Cilj rada je bio da se ispitaju sintaksička svojstva tekstova učenika od prvog do četvrtog razreda osnovne škole i razlike u njihovoj produkciji između dečaka i devojčica, odnosno da se ispita da li na dužinu teksta i izbor određenog tipa rečenica utiče pol deteta.

\section{Ispitanici}

U istraživanju su učestvovala po dva odeljenja od prvog do četvrtog razreda beogradske osnovne škole Pavle Savić - ukupno 181 učenik (85 devojčica i 96 dečaka). Svi su bili podeljeni u 4 uzrasne grupe: 49 učenika prvog razreda (27 devojčica i 22 dečaka), 44 učenika drugog razreda (22 devojčice i 22 dečaka) i 42 učenika trećeg odnosno 46 četvrtog razreda (16 devojčica u trećem i 20 u četvrtom; 26 dečaka u trećem i 26 u četvrtom razredu). Ispitanici su pisali po tri teksta tako da ih je u korpusu bilo ukupno 543 (Tabela I). 
SINTAKSIČKI POKAZATELJI POLNOLEKTA U KASNIJOJ FAZI JEZIČKOG ...

Tabela I Struktura ispitanika prema uzrastu i polu

\begin{tabular}{|l|l|l|}
\hline Razred & N (181) & Pol muški / ženski \\
\hline prvi & 49 & $22 / 27$ \\
\hline drugi & 44 & $22 / 22$ \\
\hline treći & 42 & $26 / 16$ \\
\hline četvrti & 46 & $26 / 20$ \\
\hline
\end{tabular}

\section{Metodologija}

Svako dete je dobilo isti zadatak - da tokom jednog školskog časa napiše tekst na zadatu temu. Svi su imali pisano uputstvo koje im je davalo opšte smernice i temu, ali i omogućavalo da samostalno odaberu naslov kao i ono o čemu će pisati.

Analizirani su kvantitativni i kvalitativni sintaksički parametri na nivou teksta i rečenice. Pokazatelji dužine teksta su se odnosili na ukupan broj reči kao i na broj komunikativnih rečenica i klauza u tekstu. Osim navedenih varijabli, analizirana je i dužina komunikativne rečenice na osnovu broja reči i klauza. Unutar zavisnosloženih rečenica izračunavao se i broj zavisnih klauza u odnosu na upravnu rečenicu jer, prema nekim autorima, njihov broj predstavlja jednu od bitnih komponenata stepena sintaksičke složenosti teksta (Silva, Sanchez, Abschi-Borzone, 2010, prema Ivanović, 2014). Uzimajući u obzir uzrast dece, u prvom i drugom razredu je pisan po jedan narativni, deskriptivni i ekspozitorni tekst, odnosno u trećem i četvrtom po jedan narativni, ekspozitorni i argumentativni tekst. Tematska i žanrovska raznovrsnost je omogućila uslove za pojavu većeg broja različitih tipova rečenica, ali se prilikom obrade prikupljenog materijala nisu analizirala žanrovska obeležja teksta.

Statistička obrada svih navedenih varijabli urađena je softverskim paketom SPSS. Podaci u tabelama predstavljeni su parametrima deskriptivne statistike (aritmetička sredina, standardna devijacija), a za utvrđivanje međugrupnih razlika korišćena je jednofaktorska analiza varijanse (ANOVA). Analiza je obuhvatila kvantitativne (dužina teksta izražena brojem reči, komunikativnih rečenica i klauza) i kvalitativne (različiti tipovi rečenica) sintaksičke pokazatelje teksta. Analizirane su razlike među polovima u odnosu na ispitivane varijable. 


\section{REZULTATI SA DISKUSIJOM}

Kada pišu, deca produkuju tekstove različitog kvaliteta i kvantiteta. Njihovi tekstovi se međusobno razlikuju prema broju i vrsti rečenica koje su konstruisala. Da bi se procenilo da li je tekst u sintaksičkom smislu zreo ili ne, uzimaju se u obzir relevantne karakteristike pisane rečenice. Modeli rečenica mogu da variraju od (neproširenih) prostih do višestruko složenih od čega zavisi koliko je tekst dugačak (ili kratak); na dužinu teksta utiče ukupan broj reči i rečenica odnosno klauza koje je dete produkovalo u tekstu. Devojčice u nižim razredima osnovne škole pišu duže tekstove nego dečaci (Tabela II). Njihovi tekstovi su duži u odnosu na sve praćene parametre. Test međugrupnih razlika (Tabela III) je potvrdio da su ove razlike i statistički značajne $(\mathrm{p}<0,01)$, što znači da postoji veza između kvantitativnih parametara teksta i pola.

Tabela II Prosečna dužina teksta

(izražena brojem reči, komunikativnih rečenica i klauza)

\begin{tabular}{|l|lc|lc|ll|}
\hline Uzrast/pol/N & \multicolumn{2}{|c|}{ Broj reči AS (SD) } & \multicolumn{2}{|c|}{$\begin{array}{l}\text { Broj komunikativnih } \\
\text { rečenica AS (SD) }\end{array}$} & \multicolumn{2}{l|}{ Broj klauza AS (SD) } \\
\hline I muški $(22)$ & 51,41 & $(13,46)$ & 6,80 & $(1,64)$ & 11,07 & $(3,02)$ \\
\hline I ženski $(27)$ & 62,55 & $(19,67)$ & 7,32 & $(1,58)$ & 13,46 & $(3,47)$ \\
\hline II muški $(22)$ & 83,17 & $(25,53)$ & 9,20 & $(3,49)$ & 17,76 & $(6,37)$ \\
\hline II ženski $(22)$ & 127,07 & $(43,68)$ & 13,35 & $(4,32)$ & 26,88 & $(9,22)$ \\
\hline III muški $(26)$ & 69,32 & $(22,72)$ & 7,22 & $(2,78)$ & 13,77 & $(4,85)$ \\
\hline III ženski (16) & 86,85 & $(30,37)$ & 7,94 & $(2,81)$ & 16,75 & $(5,55)$ \\
\hline IV muški $(26)$ & 106,86 & $(33,73)$ & 10,31 & $(3,26)$ & 20,96 & $(5,83)$ \\
\hline IV ženski (20) & 153,90 & $(75,68)$ & 14,87 & $(8,12)$ & 30,30 & $(16,40)$ \\
\hline
\end{tabular}

Primećuje se i da su najkraće tekstove pisali dečaci u prvom, a najduže devojčice u četvrtom razredu. Takođe se zapaža da se kod dečaka za tri godine broj reči i klauza udvostručio, kao što je i broj komunikativnih rečenica porastao. Kod devojčica se za isti period broj reči i klauza povećao dva i po puta, a broj komunikativnih rečenica dva puta. Ovakakav rezultat nije neočekivan zbog činjenice da su sedmogodišnjaci tek počeli proces formalnog opismenjavanja pa im rukopis još uvek nije automatizovan; kratki tekstovi su posledica neautomatizovanosti rukopisa (Ivanović, 2014, Ivanović, 2016). Što se duže školuju i što duže pišu, deca produkuju 
tekstove koji su i u kvantitativnom i u kvalitativnom smislu znatno drugačiji od početnih, jer se promene uočavaju i na međurečeničnom i na unutarrečeničnom planu (sa uzrastom se povećava broj rečenica a njihova struktura se usložnjava). Osim toga, rezultati pokazuju da su devojčice u drugom razredu produkovale znatno veći broj reči od učenika trećeg razreda kao i da je u njihovim tekstovima produkovano skoro dvostruko više komunikativnih rečenica nego u tekstovima devetogodišnjaka. I po broju klauza su učenici drugog razreda nadmašili dužinu tekstova u trećem razredu. Neusklađenost realnih postignuća sa očekivanjima u trećem razredu može biti posledica individualnih razlika odnosno činjenice da su učenici jedne generacije sposobniji od druge. Verovatnije je ipak da su razlike u dužini teksta podstaknute različitim metodskim postupcima kojima su učenici bili izloženi (Ivanović, 2016). To znači da sposobnost za produkciju tekstova zavisi od instrukcija koje dete dobija tokom procesa opismenjavanja - dok neki učitelji insistiraju na kratkom i sažetom izražavanju, drugi neguju dugačko, razliveno kazivanje, pa se i sintaksička svojstva pisanog diskursa njihovih učenika mogu posmatrati kao posledica navika koje su deca stekla tokom usvajanja pisanog izraza.

Tabela III Rezultati ANOVA-e u proveri polnih razlika u prosečnom broju reči, komunikativnih rečenica i klauza

\begin{tabular}{|c|c|c|c|c|}
\hline & Pol (N) & AS & (SD) & Rezultati ANOVA-e \\
\hline \multirow{2}{*}{ Broj reči } & Muški (96) & 78,56 & $(32,21)$ & \multirow{2}{*}{$\begin{array}{l}F(3,177)=29,45 \\
p<, 001, \eta^{2}=, 15\end{array}$} \\
\hline & Ženski (85) & 105,32 & $(58,27)$ & \\
\hline \multirow{2}{*}{$\begin{array}{l}\text { Broj komunikativnih } \\
\text { rečenica }\end{array}$} & Muški (96) & 8,41 & $(3,20)$ & \multirow{2}{*}{$\begin{array}{l}F(3,177)=18,14 \\
p<, 001, \eta^{2}=, 10\end{array}$} \\
\hline & Ženski (85) & 10,77 & $(5,73)$ & \\
\hline \multirow[t]{2}{*}{ Broj klauza } & Muški (96) & 16,01 & $(6,37)$ & \multirow{2}{*}{$\begin{array}{l}F(3,177)=26,63 \\
p<, 001, \eta^{2}=, 13\end{array}$} \\
\hline & Ženski (85) & 21,51 & $(11,94)$ & \\
\hline
\end{tabular}

S obzirom da je rečenica osnovna jedinica komunikacije, jedan od osnovnih preduslova za razvoj pisane kompetencije u okviru opšte jezičke sposobnosti jeste sposobnost za produkciju različitih modela rečenica kako bi se i primarni i sekundarni rečenični konstituenti mogli realizovati i organizovati na odgovarajući način. Smenjivanje dugih i kratkih rečenica, prostih i složenih je poželjno i očekuje se na osnovnoškolskom uzrastu. 
Rezultati u Tabeli IV pokazuju da je na svim uzrastima najviše produkovano (osnovnih) proširenih rečenica. Kako pokazuje test međugrupnih razlika (Tabela $\mathrm{V}$ ), među devojčicama i dečacima postoje značajne razlike u konstruisanju tipova složenih rečenica - naporednosloženih $(p<0,05)$, zavisnosloženih $(p<0,05)$ i višestruko složenih $(p<0,01)$. I u ovom slučaju su devojčice produkovale veći broj svih tipova rečenica sa dva ili više predikata.

Tabela IV Prosečan broj različitih rečeničnih tipova u tekstu

\begin{tabular}{|lc|ll|lll|lll|ll|l|}
\hline Uzrast/pol/N & $\begin{array}{l}\text { Proste } \\
\text { neproširene } \\
\text { AS (SD) }\end{array}$ & $\begin{array}{l}\text { Osnovne } \\
\text { proširene } \\
\text { AS (SD) }\end{array}$ & $\begin{array}{l}\text { Naporedno- } \\
\text { složene } \\
\text { AS (SD) }\end{array}$ & $\begin{array}{l}\text { Zavisno- } \\
\text { složene } \\
\text { AS (SD) }\end{array}$ & $\begin{array}{l}\text { Višestruko } \\
\text { složene } \\
\text { AS (SD) }\end{array}$ \\
\hline I muški & $(22)$ & 0,39 & $(0,52)$ & 3,07 & $(1,41)$ & 1,30 & $(0,78)$ & 1,01 & $(0,63)$ & 0,40 & $(0,50)$ \\
\hline I ženski & $(27)$ & 0,37 & $(0,45)$ & 2,95 & $(1,35)$ & 1,46 & $(0,83)$ & 1,28 & $(0,84)$ & 0,83 & $(0,60)$ \\
\hline II muški & $(22)$ & 0,35 & $(0,46)$ & 3,48 & $(1,75)$ & 1,62 & $(0,74)$ & 1,91 & $(1,15)$ & 1,23 & $(0,79)$ \\
\hline II ženski & $(22)$ & 0,73 & $(0,61)$ & 4,26 & $(1,88)$ & 2,92 & $(1,60)$ & 2,67 & $(1,46)$ & 1,94 & $(0,94)$ \\
\hline III muški & $(26)$ & 0,24 & $(0,45)$ & 2,81 & $(1,55)$ & 1,20 & $(0,79)$ & 1,52 & $(0,88)$ & 1,00 & $(0,56)$ \\
\hline III ženski & $(16)$ & 0,08 & $(0,19)$ & 2,69 & $(1,71)$ & 1,71 & $(0,83)$ & 1,89 & $(0,96)$ & 1,10 & $(0,58)$ \\
\hline IV muški & $(26)$ & 0,14 & $(0,23)$ & 3,46 & $(2,09)$ & 2,10 & $(1,17)$ & 2,42 & $(1,03)$ & 1,55 & $(0,92)$ \\
\hline IV ženski & $(20)$ & 0,45 & $(0,79)$ & 5,00 & $(3,27)$ & 2,27 & $(1,07)$ & 3,78 & $(2,68)$ & 2,72 & $(2,00)$ \\
\hline
\end{tabular}

Pojedini autori izjednačavaju sintaksičku zrelost teksta (sposobnost da se produkuju i razumeju sintaksički kompleksne konstrukcije) sa sintaksičkom fluentnošću (raznovrsnost rečenica koje se javljaju u tekstu) (Mellon, 1969, prema Faigley, 1980). U tom smislu može se reći da se sposobnost za pisanu produkciju dece u nižim razredima osnovne škole postepeno proširuje, napredujući od jednostavnih ka sve složenijim konstrukcijama, čime i njihov pisani diskurs postaje u sintaksičkom smislu zreliji jer se povećava broj konstrukcija sa zavisnim klauzama. Tekstovi devojčica su duži, istovremeno je i njihova sintaksička struktura složenija jer formiraju veći broj zavisnosloženih i višestruko složenih rečenica. Pitanja koja se ovde moraju uzeti u obzir su sledeća: koji se tipovi zavisnih klauza usvajaju ranije a koje vrste zavisnih rečenica za decu predstavljaju teškoću i da li prilikom upotrebe ovih konstrukcija u pisanom diskursu postoje razlike koje se mogu dovesti u vezu sa polom. Prethodno bi se moglo i ovako formulisati: da li tekstovi devojčica na mlađem školskom 
uzrastu imaju viši stepen sintaksičke zrelosti (tj. složenosti) zato što su u njihovim tekstovima frekventnije konstrukcije sa zavisnim klauzama i da li se to svojstvo može uzeti kao sintaksički pokazatelj polnolekta. Na osnovu rezultata iznetim u prethodnoj tabeli reklo bi se da su devojčice u sintaksičkom smislu zrelije, međutim, konačan odgovor ćemo dobiti nakon analize zavisnih klauza koje su se javile u tekstovima devojčica i dečaka; ne ispuštajući iz vida činjenicu da zavisne klauze između sebe značajno variraju prema stepenu kompleksnosti.

Kako u periodu usvajanja govornog izraza (rana faza jezičkog razvoja) tako i u okviru usvajanja pisanog diskursa (kasniji jezički razvoj), zavisne klauze mogu predstavljati teškoću za dete jer spadaju u jedne od najsloženijih konstrukcija u jeziku uopšte. Da bi dete moglo da ih obradi na pravi način, ono najpre mora da usvoji strukturu proste rečenice kako bi kasnije na tu osnovu moglo da nadogradi različite vrste zavisnih klauza (Elman, 1993, Newport, 1990, prema Diessel, 2004). Zbog toga su i prve zavisnosložene rečenice relativno jednostavne strukture, što upućuje na zaključak da se ne usvajaju sve vrste zavisnih klauza istovremeno i na isti način, već različiti tipovi zavisnih klauza podrazumevaju postupnost $\mathrm{i}$ različite strategije usvajanja.

Tabela V Rezultati ANOVA-e u proveri polnih razlika u produkciji različitih tipova rečenica

\begin{tabular}{|c|c|c|c|c|c|}
\hline Rečenični tipovi & Pol & $(\mathrm{N})$ & AS & (SD) & Rezultati ANOVA-e \\
\hline \multirow{2}{*}{$\begin{array}{l}\text { Proste neproširene } \\
\text { rečenice }\end{array}$} & Muški & (96) & 0,27 & $(0,43)$ & \multirow{2}{*}{$\begin{array}{l}F(7,173)=2,874 \\
p>, 05, \eta^{2}=, 016\end{array}$} \\
\hline & Ženski & (85) & 0,43 & $(0,59)$ & \\
\hline \multirow{2}{*}{$\begin{array}{l}\text { Osnovne proširene } \\
\text { rečenice }\end{array}$} & Muški & (96) & 3,20 & $(1,73)$ & \multirow{2}{*}{$\begin{array}{l}F(7,173)=3,150 \\
p>, 05, \eta^{2}=, 018\end{array}$} \\
\hline & Ženski & (85) & 3,72 & $(2,29)$ & \\
\hline \multirow{2}{*}{$\begin{array}{l}\text { Naporednosložene } \\
\text { rečenice }\end{array}$} & Muški & (96) & 1,57 & $(0,95)$ & \multirow{2}{*}{$\begin{array}{l}F(7,173)=12,077 \\
p<, 05, \eta^{2}=, 065\end{array}$} \\
\hline & Ženski & (85) & 2,0 & $(1,26)$ & \\
\hline \multirow{2}{*}{$\begin{array}{l}\text { Zavisnosložene } \\
\text { rečenice }\end{array}$} & Muški & $(96)$ & 1,7 & $(1,06)$ & \multirow{2}{*}{$\begin{array}{l}F(7,173)=12,260 \\
p<, 05, \eta^{2}=, 066\end{array}$} \\
\hline & Ženski & (85) & 2, & $(1,86)$ & \\
\hline \multirow{2}{*}{$\begin{array}{l}\text { Višestruko složene } \\
\text { rečenice }\end{array}$} & Muški & (96) & & $(0,81)$ & \multirow{2}{*}{$\begin{array}{l}F(7,173)=17,094 \\
p<, 01, \eta^{2}=, 090\end{array}$} \\
\hline & Ženski & (85) & 1,61 & $(1,36)$ & \\
\hline
\end{tabular}

Poslednjih godina se sva ispitivanja merenja stepena sintaksičke zrelosti teksta uglavnom zasnivaju na spremnosti deteta da produkuje i razume zavisne kaluze. 
Maja P. Ivanović / Jelena P. Đorđević

Tabela VI Prosečan broj različitih tipova

zavisnih klauza u zavisnosloženim rečenicama u tekstu

\begin{tabular}{|c|c|c|c|c|c|}
\hline Uzrast/pol /N & $\begin{array}{l}\text { Izrične } \\
\text { AS (SD) }\end{array}$ & $\begin{array}{l}\text { Odnosne } \\
\text { AS (SD) }\end{array}$ & $\begin{array}{l}\text { Mesne } \\
\text { AS (SD) }\end{array}$ & $\begin{array}{l}\text { Vremenske } \\
\text { AS (SD) }\end{array}$ & $\begin{array}{l}\text { Uzročne } \\
\text { AS } \quad \text { (SD) }\end{array}$ \\
\hline I muški (22) & $0,26 \quad(0,32)$ & $0,11 \quad(0,19)$ & / & $0,42 \quad(0,31)$ & $0,24 \quad(0,36)$ \\
\hline I ženski (27) & $0,42 \quad(0,43)$ & $0,13 \quad(0,23)$ & / & $0,41 \quad(0,40)$ & $0,35 \quad(0,33)$ \\
\hline II muški (22) & $0,73 \quad(0,77)$ & $0,21 \quad(0,39)$ & $0,01 \quad(0,07)$ & $0,74 \quad(0,47)$ & $0,33 \quad(0,46)$ \\
\hline II ženski (22) & $1,00 \quad(0,89)$ & $0,29 \quad(0,43)$ & $0,04 \quad(0,12)$ & $0,98 \quad(0,77)$ & $0,54 \quad(0,45)$ \\
\hline III muški (26) & $0,60 \quad(0,46)$ & $0,22 \quad(0,27)$ & $0,01 \quad(0,06)$ & $0,26 \quad(0,42)$ & $0,44 \quad(0,33)$ \\
\hline III ženski (16) & $0,75 \quad(0,60)$ & $0,56 \quad(0,50)$ & $0,02 \quad(0,08)$ & $0,50 \quad(0,44)$ & $0,52 \quad(0,42)$ \\
\hline IV muški (26) & $1,15 \quad(0,72)$ & $0,32 \quad(0,37)$ & $0,02 \quad(0,09)$ & $0,60 \quad(0,51)$ & $0,49 \quad(0,41)$ \\
\hline IV ženski (20) & $2,06 \quad(2,37)$ & $0,85 \quad(0,68)$ & $0,03 \quad(0,10)$ & $0,56 \quad(0,38)$ & $0,63 \quad(0,47)$ \\
\hline
\end{tabular}

Tradicionalna gramatika nezavisne klauze i zavisne klauze sa priloškom funkcijom posmatra kao kategorijalno različite. Međutim, za Dizela obe vrste rečenica predstavljaju jedan kontinuum srodnih, povezanih konstrukcija (Diessel, 2004). Sledeći Dizela, vremenske i uzročne klauze (koje su u analiziranom korpusu tekstova među najbrojnijim), na primer, predstavljaju tačku u kojoj se prelamaju karakteristike i koordinacije i subordinacije jer obe vrste spadaju u one koje deca najranije usvajaju (Tabela 6). Dete ih najčešće konstruiše tako što ih jednostavno samo doda na upravnu rečenicu, na isti način kao kada formira neku naporednu konstrukciju. Pored zavisnih klauza sa funkcijom priloških odredaba za vreme i uzrok, među prvima se usvajaju i klauze sa dopunskom konstituentskom funkcijom - izrične, koje imaju visoku frekvencu upotrebe s obzirom da se javljaju kao dopuna uz tranzitivne glagole i da njihovu upotrebu u velikoj meri olakšava sama semantika glagola (rekcija glagola navodi dete da konstruiše dopunu u vidu izrične rečenice); i namerne, koje su deca u našem istraživanju najčešće upotrebljavala uz glagole svesno preduzetog kretanja pa su imale dopunsku (a ne odredbenu) funkciju, što ih, na izvestan način, približava modelu izričnih rečenica (Tabele, VI, VIa). 
SINTAKSIČKI POKAZATELJI POLNOLEKTA U KASNIJOJ FAZI JEZIČKOG ...

Tabela VIa Prosečan broj različitih tipova zavisnih klauza u zavisnosloženim rečenicama u tekstu (nastavak)

\begin{tabular}{|c|c|c|c|c|c|c|}
\hline \multicolumn{2}{|c|}{ Uzrast/pol/N } & \begin{tabular}{|l}
\multicolumn{2}{|l}{ Uslovne } \\
AS $\quad$ (SD)
\end{tabular} & \begin{tabular}{|l}
\multicolumn{2}{c}{ Dopusne } \\
AS (SD)
\end{tabular} & $\begin{array}{l}\text { Namerne } \\
\text { AS (SD) }\end{array}$ & $\begin{array}{l}\text { Poredbene } \\
\text { AS (SD) }\end{array}$ & $\begin{array}{l}\text { Posledične } \\
\text { AS (SD) }\end{array}$ \\
\hline I muški & $(22)$ & / & / & $0,09 \quad(0,15)$ & I & $0,01 \quad(0,07)$ \\
\hline I ženski & (27) & $0,01 \quad(0,06)$ & / & $0,17 \quad(0,30)$ & $0,06 \quad(0,16)$ & $0,03 \quad(0,11)$ \\
\hline II muški & $(22)$ & I & / & $0,19 \quad(0,22)$ & $0,06 \quad(0,13)$ & / \\
\hline II ženski & $(22)$ & $0,01 \quad(0,07)$ & $0,04 \quad(0,15)$ & $0,26 \quad(0,42)$ & $0,13 \quad(0,24)$ & $0,03 \quad(0,10)$ \\
\hline III muški & $(26)$ & $0,07 \quad(0,17)$ & / & $0,14 \quad(0,25)$ & $0,26 \quad(0,09)$ & I \\
\hline III ženski & $(16)$ & $0,12 \quad(0,17)$ & $0,04 \quad(0,17)$ & $0,12 \quad(0,17)$ & $0,04 \quad(0,11)$ & I \\
\hline IV muški & $(26)$ & $0,14 \quad(0,25)$ & / & $0,26 \quad(0,36)$ & $0,03 \quad(0,09)$ & $0,01 \quad(0,06)$ \\
\hline IV ženski & (20) & $0,20 \quad(0,27)$ & $0,01 \quad(0,07)$ & $0,28 \quad(0,31)$ & $0,08 \quad(0,26)$ & $0,01 \quad(0,07)$ \\
\hline
\end{tabular}

Zavisne klauze sa priloškom funkcijom se unutar svoje grupe razlikuju po stepenu uključenosti u upravnu klauzu - one koje odlikuje labavija veza sa glavnom rečenicom su frekventnije (vremenske i uzročne), a one koje su u čvršćoj vezi, kao štu su poredbene i uslovne na primer, javile su se izuzetno retko - nije ih bilo u tekstovima dečaka prvog razreda, a uslovnih ni kod dečaka u drugom razredu (Tabela VIa). Pored njih, mesne rečenice nije upotrebilo nijedno dete u prvom razredu, a dopusne su tek sporadično upotrebile devojčice na višim uzrastima. Iz ovoga sledi da se pojedine podvrste zavisnih klauza usvajaju nakon desete godine, odnosno da je njihov period usvajanja znatno duži od vremena koje je detetu potrebno da usvoji ostale tipove zavisnih klauza. Inače, mesne rečenice se i kod odraslih govornika veoma retko upotrebljavaju zbog toga što je u duhu srpskog jezika da se priloška odredba za mesto iskazuje predloškopadežnom konstrukcijom a ne klauzom, pa ih u tom smislu nismo mogli očekivati u većem broju ni kod dece ranog školskog uzrasta. Iako sa statističkog aspekta postoji razlika između dečaka i devojčica koja je značajna u produkciji uzročnih, dopusnih i poredbenih rečenica $(\mathrm{p}<0,05)$, smatramo da ona nije posledica biologije, ili bar ne u potpunosti (Tabele VII, VIIa). Pojava velikog broja uzročnih rečenica se pre može dovesti u vezu sa tipom teksta nego sa polom deteta. Da bi objasnila sličnosti i razlike između zime i leta (ekspozitorni tekst), deca su najviše koristila uzročne rečenice, što ovaj tip klauza čini osetljivim na žanr teksta. S druge strane, mišljenja smo da mali broj poredbenih, a naročito dopusnih klauza i kod devojčica 
Maja P. Ivanović / Jelena P. Đorđević

i kod dečaka potvrđuje pretpostavku da su ove rečenice još uvek u fazi usvajanja kod dece mlađeg školskog uzrasta, te da ni u tom slučaju ne može biti reč o jednoj od odlika polnolekta.

Tabela VII Rezultati ANOVA-e u proveri polnih razlika u odnosu na prosečan broj različitih tipova zavisnih klauza u zavisnosloženim rečenicama u tekstu

\begin{tabular}{|l|ll|ll|l|}
\hline Zavisne rečenice & Pol/N & AS & $(\mathrm{SD})$ & Rezultati ANOVA-e \\
\hline \multirow{3}{*}{ Izrične rečenice } & Muški & $(96)$ & 0,70 & $(0,67)$ & $\mathrm{F}(7,173)=6,39$, \\
\cline { 2 - 6 } & Ženski & $(85)$ & 1,01 & $(1,41)$ & $\mathrm{p}<, 05, \eta^{2}=, 036$ \\
\hline \multirow{3}{*}{ Odnosne rečenice } & Muški & $(96)$ & 0,22 & $(0,32)$ & $\mathrm{F}(7,173)=17,00$, \\
& Ženski & $(85)$ & 0,42 & $(0,54)$ & $\mathrm{p}<, 01, \eta^{2}=, 089$ \\
\hline \multirow{3}{*}{ Mesne rečenice } & Muški & $(96)$ & 0,01 & $(0,07)$ & $\mathrm{F}(7,173)=0,99$, \\
\cline { 2 - 5 } & Ženski & $(85)$ & 0,02 & $(0,09)$ & $\mathrm{p}>, 05, \eta^{2}=, 006$ \\
\hline \multirow{3}{*}{ Uzročne rečenice } & Muški & $(96)$ & 0,50 & $(0,47)$ & $\mathrm{F}(7,173)=2,12$, \\
\cline { 2 - 5 } & Ženski & $(85)$ & 0,61 & $(0,56)$ & $\mathrm{p}>, 05, \eta^{2}=, 012$ \\
\cline { 2 - 5 } & Ženski & $(96)$ & 0,38 & $(0,40)$ & $\mathrm{F}(7,173)=4,84$, \\
& & & 0,50 & $(0,42)$ & $\mathrm{p}<, 05, \eta^{2}=, 027$ \\
\hline
\end{tabular}

Tabela VIIa Rezultati ANOVA-e u proveri ppolnih razlika u odnosu na prosečan broj različitih tipova zavisnih klauza u zavisnosloženim rečenicama u tekstu

\begin{tabular}{|l|ll|ll|l|}
\hline Zavisne rečenice & Pol & AS & (SD) & Rezultati ANOVA-e \\
\hline \multirow{2}{*}{ Uslovne rečenice } & Muški & $(96)$ & 0,05 & $(0,17)$ & $\mathrm{F}(7,173)=1,97$, \\
\cline { 2 - 5 } & Ženski & $(85)$ & 0,07 & $(0,17)$ & $\mathrm{p}>, 05, \mathrm{n}^{2}=, 011$ \\
\hline \multirow{2}{*}{ Dopusne rečenice } & Muški & $(96)$ & $/$ & & $\mathrm{F}(7,173)=4,97$, \\
\cline { 2 - 5 } & Ženski & $(85)$ & 0,02 & $(0,11)$ & $\mathrm{p}<, 05, \mathrm{n}^{2}=, 028$ \\
\hline \multirow{2}{*}{ Pamerne rečenice } & Muški & $(96)$ & 0,17 & $(0,26)$ & $\mathrm{F}(7,173)=0,77$, \\
\cline { 2 - 5 } & Ženski & $(85)$ & 0,21 & $(0,32)$ & $\mathrm{p}>, 05, \mathrm{n}^{2}=, 004$ \\
\hline \multirow{2}{*}{ Posledične rečenice rečenice } & Muški & $(96)$ & 0,02 & $(0,09)$ & $\mathrm{F}(7,173)=5,06$, \\
\cline { 2 - 5 } & Ženski & $(85)$ & 0,08 & $(0,20)$ & $\mathrm{p}<, 05, \mathrm{n}^{2}=, 028$ \\
\cline { 2 - 5 } & Zuški & $(96)$ & 0,006 & $(0,05)$ & $\mathrm{F}(7,173)=1,83$, \\
\cline { 2 - 5 } & Ženski & $(85)$ & 0,02 & $(0,08)$ & $\mathrm{p}>, 05, \mathrm{n}^{2}=, 01$ \\
\hline
\end{tabular}

Pažnju, kako smatraju pojedini autori, treba obratiti na to da li u tekstovima raste broj zavisnih klauza sa pridevskom vrednošću (funkcija ime- 
ničkih odredaba), koje se smatraju jednim od važnijih kriterijuma za procenu stepena sintaksičke zrelosti teksta. Statistički značajna razlika na nivou $\mathrm{p}<0,01 \mathrm{u}$ produkciji zavisnih klauza između dečaka i devojčica je samo u produkciji odnosnih rečenica (Tabela VII) iz čega bi se mogao izvući zaključak da su tekstovi devojčica na sintaksičkom planu zreliji, te da bi ova karakteristika mogla da predstavlja jedno od stvarnih obeležja polnolekta. Međutim, kako ovaj tip rečenica ravnomerno raste i kod devojčica i kod dečaka smatramo da je ovaj tip zavisnih klauza još uvek u procesu usvajanja, tim pre što se struktura relativnih klauza tokom školovanja usložnjava - od konstrukcija koje su suštinski, iako ne i formalno, proste, nakon nekoliko godina se postepeno stiže do nivoa (tipične) relativne klauze koja se, tek tada, suštinski uključuje u strukturu rečenice koja joj je nadređena. Jednostavnija verzija odnosnih rečenica (prezentativne relativne klauze) javlja se u najvećem broju primera i kod devojčica i kod dečaka pa ih u tom smislu ne možemo smatrati prestižnim u odnosu na ostale vrste zavisnih klauza.

U relevantnoj literaturi se sve češće uspostavlja čvršća veza između dužine rečenice i sintaksičke zrelosti teksta na taj način što se traga za jasnim odgovorom na pitanje kako se sve rečenica može produžavati. U Tabeli VIII se vidi da devojčice produkuju duže rečenice (tj. generišu veći broj reči i klauza unutar komunikativne rečenice) i duže klauze (merene brojem reči). Test međugrupnih razlika (Tabela IX) je pokazao da značajnost razlika između dečaka i devojčica postoji u dužini rečenice koja se izračunava brojem reči i klauza $(p<0,05)$.

Od svih parametara na nivou rečenice najmanje je pouzdan broj reči jer nam ne pokazuje strukturu rečenice. Korisnija mera je broj klauza u okviru komunikativne rečenice jer se na osnovu nje, posredno, može zaključiti sa koliko klauza je dete u stanju da se nosi u pisanom diskursu. Međutim, kako su deca, naročito u prvom i drugom razredu sklona produkovanju velikog broja naporednosloženih rečenica tako što jednostavno ređaju nezavisne klauze gomilajući predikate (što implicira i niži nivo sintaksičke zrelosti teksta), često bez ijednog znaka interpunkcije, onda se više pažnje poklanja dužini klauze tj. broju reči u klauzi. Kako je smatrala La Brantova (La Brant, 1933; Hunt, 1965, prema Hunt, 1965), dužina klauze, ni glavne ni zavisne, nije značajan pokazatelj sintaksičkog razvoja za decu u osnovnoj i srednjoj školi zbog toga što ta mera jako sporo raste, što potvrđuju i naši rezultati. Kako je pokazano, za tri godine je broj reči u klauzi kod devojčica porastao za 0,55 a kod dečaka za 0,39 (Tabela VIII). 
Maja P. Ivanović / Jelena P. Đorđević

Tabela VIII - Prosečna dužina rečenice izražena brojem reči i klauza; prosečan broj zavisnih klauza u zavisnosloženoj rečenici; prosečna dužina klauze izražena brojem reči

\begin{tabular}{|c|c|c|c|c|}
\hline Uzrast/pol/N & $\begin{array}{l}\text { Broj reči u } \\
\text { komunika- } \\
\text { tivnoj rečenici } \\
\text { AS } \quad \text { (SD) }\end{array}$ & $\begin{array}{l}\text { Broj klauza } \\
\text { u komunika- } \\
\text { tivnoj rečenici } \\
\text { AS } \quad \text { (SD) }\end{array}$ & $\begin{array}{l}\text { Br. zav. } \\
\text { klauza u } \\
\text { zavslož. r. AS } \\
\text { (SD) }\end{array}$ & $\begin{array}{l}\text { Broj reči } \\
\text { u klauzi } \\
\text { AS } \quad \text { (SD) }\end{array}$ \\
\hline I muški (22) & $7,63 \quad(1,50)$ & $1,63 \quad(0,30)$ & $1,19 \quad(0,35)$ & $4,67 \quad(0,46)$ \\
\hline I ženski (27) & $8,56 \quad(1,81)$ & $1,85 \quad(0,37)$ & $1,27 \quad(0,34)$ & $4,62 \quad(0,55)$ \\
\hline II muški (22) & $(1,60)$ & $1,95 \quad(0,27)$ & $1,22(0,30)$ & $4,78 \quad(0,47)$ \\
\hline II ženski (22) & $9,53 \quad(1,20)$ & $2,01 \quad(0,23)$ & $1,25 \quad(0,22)$ & $4,72 \quad(0,26)$ \\
\hline III muški (26) & $9,95 \quad(2,16)$ & $1,95 \quad(0,34)$ & $1,19 \quad(0,22)$ & $5,11 \quad(0,68)$ \\
\hline III ženski (16) & $11,05 \quad(1,83)$ & $2,13 \quad(0,34)$ & $1,37 \quad(0,25)$ & $5,20 \quad(0,41)$ \\
\hline IV muški (26) & $10,48 \quad(1,64)$ & $2,07 \quad(0,32)$ & $1,25 \quad(0,23)$ & $5,06 \quad(0,35)$ \\
\hline IV ženski (20) & $10,61 \quad(1,86)$ & $2,05 \quad(0,33)$ & $1,26 \quad(0,19)$ & $5,17 \quad(0,44)$ \\
\hline
\end{tabular}

Tabela IX rezultati ANOVA-e u proveri polnih razlika u prosečnoj dužini rečenice izražene brojem reči i klauza; u prosečnom broju zavisnih klauza u zavisnosloženoj rečenici i u prosečnoj dužini klauze izraženoj brojem reči

\begin{tabular}{|c|c|c|c|c|}
\hline & $\mathrm{Pol} / \mathrm{N}$ & AS & (SD) & Rezultati ANOVA-e \\
\hline \multirow[t]{2}{*}{ Broj reči u rečenici } & Muški (96) & 9,42 & $(2,04)$ & \multirow{2}{*}{$\begin{array}{l}F(7,169)=4,950, \\
p<, 05, \eta^{2}=, 028\end{array}$} \\
\hline & Ženski (85) & 9,79 & $(1,92)$ & \\
\hline \multirow[t]{2}{*}{ Broj klauza u rečenici } & Muški (96) & 1,91 & $(0,35)$ & \multirow{2}{*}{$\begin{array}{l}F(7,169)=5,376, \\
p<, 05, \eta^{2}=, 031\end{array}$} \\
\hline & Ženski (85) & 2,00 & $(0,33)$ & \\
\hline \multirow{2}{*}{$\begin{array}{l}\text { Broj zavisnih klauza u } \\
\text { zavisnoslož. reč. }\end{array}$} & Muški (96) & 1,21 & $(0,27)$ & \multirow{2}{*}{$\begin{array}{l}F(7,169)=3,362, \\
p>, 05, \eta^{2}=, 020\end{array}$} \\
\hline & Ženski (85) & 1,28 & $(0,26)$ & \\
\hline \multirow[t]{2}{*}{ Broj reči u klauzi } & Muški (96) & 4,92 & $(0,53)$ & \multirow{2}{*}{$\begin{array}{l}F(7,169)=0,114, \\
p>, 05, \eta^{2}=, 001\end{array}$} \\
\hline & Ženski (85) & 4,89 & $(0,50)$ & \\
\hline
\end{tabular}

Broj reči u komunikativnoj rečenici na svim uzrastima kod oba pola manje-više ravnomerno raste, ali ova mera ništa ne govori o strukturi rečenice.

Imajući ovo na umu, La Brantova je još u prvoj polovini prošlog veka smatrala da je za procenu sintaksičkog razvoja važan procenat zavisnih klauza odnosno indeks subordinacije koji se izračunava tako što se broj glavnih rečenica (jedan) podeli brojem zavisnih klauza koje je dete produkovalo 
u komunikativnoj rečenici (La Brant, 1933 prema Hunt, 1965). Smatra se da ovaj procenat raste do okončanja srednje škole, pa i nakon toga. Ukoliko dete češće koristi sintagmatske konstrukcije to objašnjava porast broja reči odnosno dužu klauzu, a ukoliko umeće zavisne klauze to vodi produžavanju komunikativne rečenice na nivou ukupnog broja reči ali i na nivou broja klauza (Hunt, 1965). Broj zavisnih klauza unutar zavisnosloženih rečenica raste, doduše sporo, i kod devojčica i kod dečaka, ali nam on može poslužiti kao čvrst dokaz da se sposobnost za pisanu produkciju postepeno proširuje i da u tom smislu nema razlika između dečaka i devojčica u osnovnoj školi, ukoliko je, naravno, reč o deci sa tipičnim jezičkim razvojem.

\section{ZAKLJUČAK}

Rezultati u ovom radu upućuju na zaključak da postoji značajna razlika u dužini tekstova između dečaka i devojčica. Devojčice su produkovale duže tekstove u odnosu na ukupan broj reči, komunikativnih rečenica i u odnosu na ukupan broj klauza. Komunikativna rečenica merena brojem reči i klauza takođe je značajno duža u tekstovima koje su pisale devojčice. Kad je reč o strukturi teksta, značajno veći broj svih vrsta složenih rečenica (naporednosložene, zavisnosložene i višestruko složene) takođe produkuju devojčice. Međutim, razlike nisu značajne kad je reč o tipovima zavisnih klauza, mada je i njih u proseku više kod devojčica.

Ne bi se moglo, na osnovu analiziranih parametara teksta i rečenice, tvrditi da je jezička sposobnost devojčica na mlađem školskom uzrastu na višem nivou nego kod dečaka; te prednosti su zanemarljive iz čega se može zaključiti da nema polnih, tj. bioloških razlika u načinu jezičkog funkcionisanja (Ivanović, 2014). Ne postoje suštinske razlike u načinu obrade jezičkih podataka (Berko-Gleason \& Ely, 1997) što ipak ne znači da razlika nema - analiza prikupljenih tekstova nam je pokazala da se devojčice i dečaci ponekad, čak često, jezikom služe na različite načine, međutim, te razlike ne zadiru dublje u strukturu, više su površinske nego dubinske. Tamo gde se razlike primećuju, uglavnom su devojčice uspešnije, ali se one još uvek ne mogu dovesti u vezu sa biološkim faktorima.

$\mathrm{Na}$ osnovu iznetih rezultata može se zaključiti da se razlike između tekstova dečaka i devojčica na mlađem osnovnoškolskom uzrastu odnose na kvantitativne pokazatelje, dok u stepenu sintaksičke zrelosti tekstova nema značajnih razlika. 
Maja P. Ivanović / Jelena P. Đorđević

\section{LITERATURA}

Berko-Gleason, J. \&Ely, R. (1997). Gender differences in language development. In: (McGillicuddy-De Lisi, A. V., \& R. De Lisi, eds.) Biology, Society and Behaviour: The Development of Sex Differences in Cognition. Boston: Allyn \& Bacon.

Bodine A. (1975). Androcentrism in prescriptive grammar: singular 'they', sexindefinite 'he', and 'he or she'. Lang. Soc. 4 129-146.

Butler, J. (1990). Gender trouble: feminism and the subversion of identity. Abingdon: Routledge.

Diessel, H. (2004). The acquisition of complex sentences. Cambridge Studies in Linguistics, 105. Cambridge: University Press, Cambridge.

Faigley, L. (1980). Names in search of a concept: maturity, fluency, complexity and growth in written syntax. College Composition and Communication, 31/3, 291-300.

Filipović, J. (2011). Rod i jezik (Gender and language). In: Uvod u rodne teorije (Introduction to gender theories) (Ivana Milojević \& Slobodanka Markov, eds.). Novi Sad: Centar za rodne studije \& Mediterran Publishing, 409423.

Hunt, K. W. (1965). Grammatical structures written and three grade levels (Research report No.3). Champaign, IL: National Council of Teachers of English.

Ivanović, M. (2014). Sintaksičke konstrukcije u pisanom diskursu dece uzrasta od sedam do deset godina. Beograd: Filološki fakultet (doktorska disertacija).

Ivanović, M. (2016). Sintaksička svojstva pisanog diskursa učenika mlađeg osnovnoškolskog uzrasta - longitudinalni pristup. Zbornik Instituta za pedagoška istraživanja 48/1, 87-105.

Lakoff, R. (1975). Language and woman's place. New York: Harper\& Row.

McKee, G. (2009). Approaches to gender and communication. Gender and Communication [Online].Learning Seed. http://www.learningseed .com /_guides /1172_gender_and_communication_guide.pdf [2014, April]

Rathmayr, K. (2014). Genderlect: The verbal battle for female intimacy and male independence. (bachelor theses).

Savić, S. (1995). Jezik i pol I: istraživanja u svetu, Ženske studije. Beograd, 1, 197-209.

Talbot, M. (2010). Language and gender. Cambridge: Polity Press.

Tannen, D. (1990). You just don't understand: Women and men in conversation. London:Virago Press.

Tannen, D. (1994). Gender and discourse. New York: Oxford University Press. 


\title{
Maja Ivanović \\ Jelena Đorđević
}

\section{SINTACTIC INDICATORS OF GENDERLECT IN LATER LANGUAGE DEVELOPMENT}

\begin{abstract}
Summary
Men and women use language means in various ways, the means of the same language, when they speak and write. This is the essence of genderlect theory which tries to explain what these differences are, and such theory incited numerous researches in current years.

The aim of this work is to investigate syntactic features of youngest school age students' texts and differences in that production between boys and girls. 181 pupils participated in this research from the first, up to the fourth grade (96 boys and 85 girls). Each student wrote three essays, so there were 543 texts in this corpus. Our study included moth quantitative (the text length presented by a number of words, communicative sentences and clauses; the length of the sentence presented by a number of words and clauses) and qualitative (various sentences types) indicators. Differences between genders were analysed in comparison to researched variables.

The results proved that there exist statistically significant differences in text length and sentence length in comparison to all measured parameters, i.e. girls produce longer texts and sentences than boys. When text structure is in question, it is important that the greatest number of complex sentences (compound, complex and complex-compound), are also constructed by girls. However, differences are not significant in relation, though they occur more often in the girls' texts.

Our results show that there are certain quantitative differences between girls and boys at younger elementary school age with respect of some syntactic features, while in terms of syntactic maturity, i.e. the complexity of the produced texts there are no significat differences.
\end{abstract}

Keywords: writing, syntax, differences, gender, genderlect, later language development 